Article

\title{
Organizational Orientations, Industrial Category, and Responsible Innovation
}

\author{
Christine Chou \\ Department of International Business, National Dong Hwa University, Hualien 97401, Taiwan; \\ chou@gms.ndhu.edu.tw
}

Received: 22 February 2018; Accepted: 28 March 2018; Published: 30 March 2018

\begin{abstract}
This paper explores the foundations of firms' involvement in responsible innovation. A number of hypotheses appearing in the literature, regarding the direct effect of strategic orientations and the moderating effect of industrial category on responsible innovation engagement, were tested by using text analytics and statistical methods. The data comprise 475 documents of firms' annual reports with a total word count of 192,179,794 and a mean of 404,589, supplemented with corresponding financial data, yielding 372 firm-year observations. The results show that long-term orientation and organizational virtue orientation are positively associated with responsible innovation, while profitability orientation is negatively correlated. The results also show that industrial category moderates the relationship between strategic orientations and responsible innovation engagement, such that the positive relationship between both long-term and organizational virtue orientation and responsible innovation is weaker in the industrial products category than in the consumer products category. The theoretical and practical implications are discussed.
\end{abstract}

Keywords: responsible innovation; text analytics; strategic foundation; organizational virtue orientation; industrial category

\section{Introduction}

Innovation is the process of translating an idea or invention into a good or service that creates value or for which customers will pay [1]. To make an innovation successful, firms must strive to maximize the benefit to customers and to the firms themselves. Such a rule of innovation can improve the welfare of all parties [2]. However, this philosophy has also been strongly challenged, and the disadvantages have been evident in recent years. Caution has been called for in research about technologies such as the development of DNA [3] or nanotechnology [4] due to their potential impacts on human lives and inherent social and ethical issues. As the power of technology to produce both benefits and harm has become clearer, debates about responsibility have broadened [5,6]. How a firm assumes its responsibility toward society and the environment and the economic system when it is engaged in innovation-related projects have become imperative issues for modern firms. Reflecting on this situation, some European scholars, supported by funding from the European Commission, proposed a concept called "responsible innovation" as a new norm to guide innovation activities [7].

The idea of responsible innovation has attracted increasing academic and practical attention. Although a consensual definition has not yet been established due to the term's adolescent introduction, several scholars have provided definitions for responsible innovation. von Schomberg [7] defines responsible research and innovation as "[A] transparent, interactive process by which societal actors and innovators become mutually responsive to each other with a view to the (ethical) acceptability, sustainability and societal desirability of the innovation process and its marketable products (in order to allow a proper embedding of scientific and technological advances in our society)" (p. 9). As a step further, Stilgoe, Owen and Macnaghten [3] provide a broader definition of responsible innovation, 
asserting that it "means taking care of the future through collective stewardship of science and innovation in the present" (p. 1570).

According to these definitions, including social responsibility in the innovation process or product is the core of this concept. For example, Chatfield, et al. [8] used the drivers of corporate social responsibility (CSR) in previous studies as a starting point in a search for drivers of responsible research and innovation. The importance of this concept is manifested in the increasing number of cases in which firms use technology and specific knowledge to produce products to make a profit, but do so at the expense of consumers' health and trust, or even the health of the environment. For example, BBC News reported that "[A] furious row has erupted over a French study claiming to have found tumors and other problems in rats fed on genetically modified maize and exposed to a common, associated herbicide" [9]. Although the innovation of genetically modified food helped address famine, the subsequent impacts are widely discussed and questioned. These cases cause practitioners and scholars to rethink the concept of responsible innovation and what role it can play in building a better society and protecting the environment.

Scholars have noted that the study of responsible innovation should shift from the public sector to the private sector [8] or private companies [10]. Echoing this call, this paper begins by asking what factors can affect firms' engagement with responsible innovation. Using the Austrian medical device industry as their contextual setting and case studies as their method, Auer and Jarmai [11] note that management and organizational structures can provide potential drivers for implementing responsible innovation. Additionally, scholars have proposed examining responsible innovation from two forms of organizational orientations, namely, strategic and ethical foundations $[4,12]$. This study echoes this proposal and consults previous literature to employ long-term and profitability orientations as a strategic perspective while using organizational virtue orientation as an ethical perspective to test the hypotheses. This research further introduces the concept of industrial category, which exhibits different levels of stakeholder involvement, to see how the effect of both strategic and ethical orientations on responsible innovation can be different. This study contributes to theory and practice in several aspects.

First, responsible innovation is a theoretically important issue; however, the questions of what motivates a firm to engage in responsible innovation and how the industrial environment affects this link are under-researched. These questions are important and timely because innovation management has been predominately focused on the sources of innovation and assumes that innovation is beneficial for society and economic growth [13]. However, some results of innovation have been found to be undesired and unexpected, leading to the question of how to consider the social and environmental impact in the innovation process. Studies about responsible innovation fill this theoretical gap and provide greater understanding of innovation management.

Second, this project uses a progressively validated tool, text analytics, to analyze the underlying patterns and relationships among different variables. Many scholars who study responsible innovation or CSR tend to use the database of KLD Research \& Analytics, Inc. (e.g., [14,15]). Although the KLD database can reflect the evaluation of experts, text analytics can provide data representing the idea of the focal firms. These two approaches can complement each other. Furthermore, using text analytics, this research echoes the recent call that rating for the environmental, social, and governance (ESG) indicators can help investors make decisions and lead firms to emphasize these dimensions [16]. Recently, Khalamayzer [17] reports that "[I]n January 2017, investment solutions provider ISS (Institutional Shareholder Services) bought IW Financial, a U.S. firm offering ESG research, consulting and portfolio management services, promising to 'help asset management firms and other institutional clients identify risks, enhance productivity and increase revenues.'" The methodology applied in this study can be used to help judge ESG ratings as a reference for investors.

Third, the study of responsible innovation is in its adolescent stage, so the full scale of research has not yet been established. Due to the exploratory nature, most previous studies used conceptual research $[3,18]$ or case studies $[4,19,20]$ to examine the nature, processes, and consequences of responsible innovation. These studies are insightful, yet the study of responsible innovation should 
move forward and perform analyses using more empirical data with diversified methods. A very recent (2017) special issue of this journal on Responsible Research and Innovation helped clarify the current development of responsible innovation in practice. The present study follows this endeavor to contribute to this stream of literature by introducing a significant amount of empirical evidence to explain the development of responsible innovation using a method combining both text analytics and panel data. Previous studies have used this mixed method to study organizational behaviors or strategic theories [21-23], yet this method is unusual, if not novel, in the study of sustainability in general and responsible innovation in particular.

Finally, this responsible innovation issue is important in practice in modern times. Recently, public awareness of wrongdoing by companies has increased, causing widespread concern or frustration regarding the conduct of firms. Determining how to solve this dilemma, namely, how to enable technological innovation while maintaining a healthy environment, is of particular importance. This study aims at contributing to this solution with a tool that can detect how innovative firms (mis)behave and how to help resolve the ethical issues that are currently occurring.

The remainder of this paper is organized as follows. The following section reviews the literature related to how strategic and virtue orientations affect engagement in responsible innovation; in addition, it reviews how industrial category differs in this process and its moderating effects. These arguments form the basis of the hypotheses investigated in this study. The subsequent section describes the research methods, the conceptual framework, the variable definitions and measures, and the data collection used in this study; this is followed by the presentation and discussion of the results. The final section discusses the implications of the findings, the limitations, and the directions for future research.

\section{Literature Review}

Although a consensual definition of responsible innovation continues to be discussed, scholars have conducted several studies attempting to investigate why firms are willing to engage in responsible innovation. Researchers have proposed examining responsible innovation based on both strategic and ethical foundations [4]; the former collaborates with "self-serving/strategic behavior", and the latter with "the right thing to do" perspectives [12]. The strategic foundation sets up the criteria for a firm to make decisions and shape the philosophical path, and can be categorized as long-term or profitability (short-term) orientations [24]. The ethical foundation, on the other hand, argues that firms adopting responsible innovation can be explained by moral or virtuous considerations $[4,25,26]$. Another well-articulated explanation of this organizational virtue orientation can be found in the study of McKenny, Short and Payne [26].

In addition, from the historical development of responsible innovation, communication with stakeholders in the industrial environment has been the key to external factors affecting the decision regarding whether firms engage in responsible innovation [27]. This trend can be supported by the study of Stilgoe, Owen and Macnaghten [3], who proposed that responsible innovation should involve four dimensions, namely, anticipation, reflexivity, inclusion, and responsiveness. All dimensions are related to the dialog or communication with stakeholders and are different among industries. This study therefore incorporates the concept of industrial category to examine whether and how the industrial category affects the organizational orientation-responsible innovation link. The rationales and related hypotheses are discussed below.

\subsection{Strategic Orientation}

Strategic orientation is "the strategic directions implemented by a firm to create the proper behaviors for the continuous superior performance of the business" [28]. It reflects a firm's philosophy or perspective on how to conduct business [29]. Recently, scholars have suggested the need to study responsible innovation from firms' strategic foundations [4]. Strategic orientation helps firms consider grand social problems such as climate change or poverty as the drivers of technological innovation [30] and is thus one of the organizational resources that lead to competitive advantage [31]. 
Using a temporal consideration, strategic orientation can be further categorized as either long-term or short-term [32]. A firm with long-term orientation emphasizes effectiveness and thus looks into the future and aims to provide the best solution that can benefit the future not only economically but also environmentally and socially. Scholars use different names, such as long-term orientation [33], long-term focus [24], or future orientation [34,35], but identical meaning to denote this approach. Long-term orientation is the tendency to prioritize the long-range implications and impact of decisions and actions that come to fruition after an extended time period [33].

When a firm has a long-term orientation, it essentially means that the future matters more than the immediate present [35]. These firms do not pursue goals that can yield only short-term gains; rather, they intend to find a sustainable solution that will offer long-term benefits. Under this guidance, firms are more willing to introduce responsibility during the process of innovation because responsibility, at its core, requires answering the question of what futures we care about [18]. Managers with this orientation tend to choose the resolution that addresses long-term value and care more about effectiveness. By implication, a long-term orientation involves persistence and patience and a commitment to dedicated resource investment over a longer time horizon [34]. Responsible innovation emphasizes that firms should take care of the future through collective actions in innovation in the present [3]. This responsibility calls for a future-minded perspective [36]. Firms with a long-term orientation therefore tend to associate with engagement in responsible innovation.

Conversely, a short-term orientation focuses on efficiency and examines the current situation and recombines all the resources to address the current problem [32]. A short-term orientation is aimed at maximizing quarterly results at the expense of long-term corporate performance [37]. Firms with a short-term orientation likely inject resources into overseeing every competitive move and engage competition through immediate response mechanisms [34]. A representative manifestation of short-term orientation is a focus on profitability. Zachary, McKenny, Short and Payne [24] regard a firm's goal focusing on profitability as aligning with the utilitarian identity of businesses. This approach corroborates the assertion of Milton Friedman's [38] article "The Social Responsibility of Business Is to Increase Its Profits."

When making critical decisions, managers usually follow the rule of achieving profitability goals, such as financial return or revenues, which usually do not need to consider the impact on the environment or societal consequence. These managers need to report their performance yearly, quarterly, or even monthly. It is difficult, if not impossible, for these managers to care more about the social or environmental consequences of their companies' innovation. That is, these firms typically target profit maximization in a short time period, whereas responsible innovation requires firms to commit resources and time to address environmental and societal issues. Regarding these arguments, this study asserts that firms with a profitability focus will be negatively associated with engagement in responsible innovation. Based on these arguments, this research therefore proposes the following hypotheses:

Hypothesis 1 (H1a). Long-term orientation is positively associated with responsible innovation engagement.

Hypothesis 1 (H1b). Profitability orientation is negatively associated with responsible innovation engagement.

\subsection{Organizational Virtue Orientation}

Organizational virtue orientation refers to an organization's integrated set of values and beliefs supporting ethical character traits and virtuous behaviors [39]. This concept originates from previous studies that applied the individual-level construct to the organizational level. As Chun [40] notes, "[T] he virtuous organization is not made by a few individual heroes, but by the collective efforts made by each member, which in turn will shape a certain degree of shared and distinctive organizational virtuous characteristics" (p. 270). Based on Chun [40], along with research regarding identity and cultural literature, Payne, Brigham, Broberg, Moss and Short [39] developed this organizational virtue 
orientation as a concept for analyzing an organization's arrangement or configuration of beliefs and values sustaining ethical character traits. This orientation is multi-dimensional and includes integrity, empathy, warmth, courage, conscientiousness, and zeal [39].

Organizational virtue orientation is a collectively formed, value-introducing disposition that guides the ethical and moral conduct of the organization [41]. Organizational virtue orientation influences organizational behaviors in two manners. First, organizational virtue orientation influences organizational processes, methods, and decisions of the organization's members to bring greater collective efforts to exhibit virtuous traits and characteristics [42]. Organizations with greater organizational virtue orientation tend to exhibit greater levels of virtuous activities, which include the choice of responsibility [36]. Under this circumstance, these firms will be willing to incorporate responsibility into the innovation process as a means of demonstrating the firm's commitment to ethical goals. Second, organizational virtue orientation is a shared culture within the organization and an important predictor of various organizational outcomes [43]. Organizational culture is path-dependent and needs to be accumulated over time. Once this culture is embedded in an organization, the organization's behavior will be guided by this culture, which benefits the adoption of responsible innovation.

Organizational virtue orientation builds a foundation for a firm to do something virtuous. Firms with such an orientation as a trait or characteristic likely adopt more responsibility in the process of innovation. For example, one dimension is integrity, which is often associated with trustfulness and honesty [40], and can lead a company to conduct their business in a virtuous manner. As such, firms tend to introduce more responsibility into the innovation process. Based on these arguments, this study proposes the following hypothesis:

Hypothesis 2 (H2). Organizational virtue orientation is positively associated with responsible innovation engagement.

\subsection{Organizational Orientations and Industrial Category}

Whereas firms' strategic and ethical orientations affect the engagement of responsible innovation, the environment of the focal firms can have a great effect on this relationship. Many studies have shown that environmental conditions have a moderating effect on the relationship between firm characteristics and firm performance [44,45]. Firms do not exist in a vacuum and are affected immensely by the industrial structure in which they are embedded. A vigorous stream of management literature has found that the best firms match the correct corporate practices to their environmental and industrial contexts [46-48]. Using the criterion of who the intended consumer or customer is, a frequently used framework for classifying products among industries distinguishes between industrial and consumer products [49]. The industrial products category comprises machinery, manufacturing plants and materials, and any other product or component used by other industries or firms. The consumer products category includes firms that produce products that are ready for consumption and the satisfaction of human wants, such as clothing or food. These two industrial categories exhibit very different industrial structures and stakeholder involvement [50], which leads to varying constraints or facilitators for engaging responsible innovation.

In fact, the beginning of the discussion regarding responsible innovation echoes the call for opening up dialog and debate with stakeholders of the focal firms to address the potential side effects of innovation [27]. Researchers further note that the idea behind responsible innovation is to democratize innovation, and the key point is to include stakeholders in the upstream innovation process [51]. The industrial products category emphasizes interfirm cooperation [50], and buyer-supplier collaboration is often discussed in the context of the industrial products category [52]. On the other hand, firms in the consumer products category usually directly face their customers without too many negotiations in the process of manufacturing and marketing [49,52].

As argued above, when firms have a long-term orientation, they are likely to engage more in responsible innovation. However, firms in the industrial products category can face more tensions in 
this process. Newly required regulations or procedures often make firms reluctant to adopt responsible innovation and sometimes causes them to abandon such innovation. For example, Yakovleva and Vazquez-Brust [53] studied mining multinationals, a classical example of the industrial products category, in Argentina, finding that at least four influential groups of stakeholders needed to be involved, including government, civil society, international financial organizations, the mining industry, and headquarters of mining multinationals. Their study further shows that the stakeholders exhibit various levels in terms of how they think the corporate responsibility of mining companies should be and which aspect to address. These different stakeholders have different perspectives, which makes responsible innovation complicated.

Similarly, the industrial category can also have an effect on the profitability orientation-responsible innovation link. In the context of this industrial products category, a firm needs to persuade more powerful stakeholders to comply or cooperate with the newly established standard or practice compared with a firm in the context of the consumer products category. When a responsible innovation involves more stakeholders in the industrial products category, firms are more constrained by these groups. Since profitability orientation is not beneficial for responsible innovation, the context of the industrial products category makes this situation worse. Voegtlin and Scherer [54] lay out a sound foundation for global governance of responsible innovation and address the regulatory environment for the development of responsible innovation.

Responsible innovation consists of innovations that avoid harming people and the planet and that improve conditions for people and the planet [54]. These require firms to engage with people from various walks of life. When a firm adopts profitability orientation, the persuasion and communication incur more costs and do not pay off in terms of the utilitarian calculation. This can worsen the already negative relationship between a firm's profitability orientation and responsible innovation engagement. Based on these arguments, this study proposes the following hypotheses:

Hypothesis 3 (H3a). The positive association between long-term orientation and responsible innovation engagement is weaker in the industrial products category than in the consumer products category.

Hypothesis $3 \mathbf{~ ( H 3 b ) . ~ T h e ~ n e g a t i v e ~ a s s o c i a t i o n ~ b e t w e e n ~ p r o f i t a b i l i t y ~ o r i e n t a t i o n ~ a n d ~ r e s p o n s i b l e ~ i n n o v a t i o n ~}$ engagement is stronger in the industrial products category than in the consumer products category.

Firms with an organizational virtue orientation tend to not only signal good quality about the focal firm but also reduce information asymmetries through the provision of more and better information [41,43]. Past research shows that virtue-oriented organizations are more likely to generate a return for their stakeholders and lead to stakeholder satisfaction $[39,40]$. The relationship between stakeholders and firms with organizational virtue orientation among industries is complex; however, a recent study shows that firms with organizational virtue orientation are interdependent with external stakeholders [41].

The level of external stakeholder involvement can be best represented in different industrial categories. Essentially, industrial products are categorized as a "gray-box approach", which means that suppliers work with the manufacturer's team members on joint product development and joint decision-making, compared with a black-box approach, in which suppliers work on their own to fulfill the manufacturers' specification [52]. Firms producing industrial products need to cooperate more with suppliers and/or manufacturers because the specification has to fit each other's production needs. On the other hand, firms concentrating on consumer products more commonly adopt the black-box approach, in which the focal firm only needs to set up the specifications for the suppliers/manufacturers to follow. The interfirm cooperation or negotiation is much less than that in industrial product networks, which consequently involve more stakeholders in the production process.

This interdependence can be seen in the engagement in responsible innovation. Whereas firms with an organizational virtue orientation can bring more responsible innovation, the context of industrial category makes a difference. These firms typically use virtues to decide whether an action 
should be taken. When faced with various influential stakeholders, as in the industrial products category, these virtues might not be very convincing to all stakeholders. This is especially true when the adoption of responsible innovation requires changes in specification or procedures within the industry, such as in the case of R-1234y Refrigerant [20]. R-1234y refrigerant is used for mobile air conditioning and is a better choice than the previous R-134a model because of its low global warming potential. However, responsible innovation requires a capacity to change shape or direction to respond to stakeholder and public values [3]. In hindsight, there should have been more deliberation among the stakeholders due to the impact on the whole car industry in addition to the high cost of developing alternatives [20]. High stakeholder involvement in the industrial products category will make the adoption of responsible innovation more challenging. Bruijnis, Blok, Stassen and Gremmen [19] proposed explaining this phenomenon using the concept of "moral lock-in" to refer to this difficulty. As they put it, " ... technologies and technological systems follow specific paths that are difficult and costly to escape. Even if potentially superior alternatives are available, these existing apparently inferior technologies and technological systems often survive for a very long time."

With these arguments and practice in mind, we observed that firms with organizational virtue orientation will compromise their adoption of responsible innovation when they are in the industrial products category, where strong or various stakeholders' demands and criteria emerge. This study thus hypothesizes that the industrial products category, compared with the consumer products category, worsens or damages the positive association between organizational virtue orientation and responsible innovation engagement. Stated formally,

Hypothesis $4 \mathbf{( H 4 ) . ~ T h e ~ p o s i t i v e ~ a s s o c i a t i o n ~ b e t w e e n ~ o r g a n i z a t i o n a l ~ v i r t u e ~ o r i e n t a t i o n ~ a n d ~ r e s p o n s i b l e ~}$ innovation engagement is weaker in the industrial products category than in the consumer products category.

\section{Materials and Methods}

\subsection{Sample}

To look for firms engaging in responsible innovation, a ranking of firms published by Fortune magazine were employed to specify the companies they considered socially responsible. Fortune magazine partnered with the Hay Group to conduct research on ranking commercial firms from best to worst, which were termed "the most and least," in several categories, including social responsibility. The ranking was conducted on a yearly basis from 2006 to 2012. Each year, Hay asked more than 10,000 executives, directors, and analysts to rate companies in their own industry in terms of eight criteria, from investment value to social responsibility (for more details, see Supplementary Material Table S2).

The ranking of social responsibility has been conducted from 2006 to 2012 (they discontinued the ranking in 2013). For example, for the 2012 ranking, this study collected the top 10 best social responsibility firms and the worst 10 ones, also, for a total of 20 firms each year. From 2006-2012, there are 7 years of observation, providing 140 firm-year observations in total. For each firm, their annual reports were collected for 4 years (the given year and the three immediately prior), resulting in 560 data points. This research used four years of annual reports for several reasons. First, the original ranking process should be presumed to represent more than one year of behavior, and using four years in the study constitutes a plausible representation of recent behavior. Second, text data are inherently noisy. To use only one year of data resulted in a sample that was simply too small and noisy to provide robust conclusions. Given the research questions, this study was limited, by current standards, to small corpora (hundreds of documents rather than hundreds of thousands or millions). The questions addressed are how to best address the situation and whether we can learn something useful from it [55]. Third, one element of the dependent variable includes innovation, whose definition has widely adopted the criteria of the OECD [56] to classify a firm as innovative if it introduced the following: (1) a new or substantially improved product in the last 3 years (product innovation) or 
(2) a new or substantially improved production process through new equipment or reengineering in the last 3 years (process innovation) [57].

After the list of firms were obtained, the Internet searches were conducted to obtain their annual reports from the year in question in addition to the prior 3 years. There were originally 560 documents. Consequently, due to the firms repeatedly ranked as either most or least socially responsible, a number of documents were duplicates, which led to a final sample of 475 . All the documents obtained were originally in PDF format. These documents were then converted into text files. The word count was $192,179,794$ in total, with a mean of 404,589.

Additionally, this study used financial data obtained from a widely used economic database, Datastream, maintained by Thomson Reuters; this provides the most comprehensive information for all sample firms. Due to some missing data, the final sample contains 372 firm-year observations including industries of Standard Industrial Classification (SIC) major groups from 10 to 89.

\subsection{Procedures}

The measures were established based on the existing literature (see below). This study then identified categories of interest by which to organize the corpus of collected documents. The documents of interest were collected, as described in the Sample section, corresponding to the categories of interest, followed by storing them and their classifications. These documents were manually downloaded and stored in folders labeled by category. Nearly all the documents were in PDF format, although a few were in Microsoft Word format; therefore, these documents of interest were converted to text format using UTF-8 encoding. After this preparation, the vocabularies of interest with which to score the documents were decided. Various concept vectors were used to report the counts of hits by different categories divided by the number of words in the document (e.g., the percentage (count/length) of the words in the document that match the category). Finally, the regression with unbalanced panel data were run to examine the relationship between each of the above concept vectors and responsible innovation engagement.

Because the data have the unbalanced panel structure with repeated observations per firm, concerns about heteroscedasticity and serial correlation across firms may arise. To address these concerns, this study estimated linear regression models for panel data that allow for heteroskedastic error structure across firms and $\mathrm{AR}(1)$ autocorrelation, where the correlation parameter is unique for each firm. A panel regression model comprised a two-way fixed-effects model that considered two sets of dummy variables (firm and year) and a random-effects model. By performing the Hausman test, this research was able to decide which model better fit the data [58].

\subsection{Measures}

\subsubsection{Dependent Variable}

The level of responsible innovation is the dependent variable in all models. Previous studies regard responsible innovation consisting of two elements: CSR and innovation. There is no existing measurement; therefore, these CSR and innovation concepts were measured separately and then combined into a single indicator. Here, this paper did not assume that the innovation activities of a firm are socially responsible. Instead, learning from previous studies, firms with high levels of CSR and innovation could be regarded as having a higher level of responsible innovation engagement. This study first addressed CSR by categorizing firms based on the rankings provided by Fortune magazine, as mentioned above. Being ranked as one of the highest-CSR firms was a proxy for a high level of engagement in social responsibility, whereas being ranked as among the worst was a proxy for a low level of engagement. Regarding innovation orientation, "innovativeness" from Short et al. [59] was used, whose sample words include "invent", "inspire", "create", and "novelty", among others. This study then combined innovativeness level with their CSR ranking to derive a score for each firm's level of responsible innovation engagement. Finally, a responsible innovation score was derived for 
each individual firm by integrating the dummy variable of CSR rankings and the "innovativeness" scores of responsible innovation engagement using the principal component method.

\subsubsection{Independent Variable}

The independent variable includes three organizational orientations, namely, long-term orientation, profitability orientation, and organizational virtue orientation. This research used established word lists to measure both strategic orientations and organizational virtue orientation based on previous literature. Specifically, long-term orientation and profitability orientation from Payne, Moore, Bell and Zachary [43] were employed. The sample words for long-term orientation include 126 words, such as "constant", "endure", "sustainable", and "nurture"; and profitability orientation includes 76 words, such as "benefit", "cost-effective", "profit", and "income". Regarding organizational virtue orientation, based on Payne, Brigham, Broberg, Moss and Short [39] and McLeod, Moore, Payne, Sexton and Evert [41], there are 232 synonyms for six organizational virtue orientation dimensions, and the sample words include "authentic", "supportive", "generous", "courageous", "accountable", and "energetic". The program was run to count the frequencies of each word and summed them to yield a score to represent the respective concept. For analysis purposes, these scores were standardized by the number of words in the annual reports. This was necessary because the annual reports exhibited a wide range in length. This study then multiplied the number by 1000 to facilitate the presentation of coefficient estimates in regression models. Therefore, this variable denotes the frequency of references to annual report value per 1000 words. This procedure is adopted by various previous studies [39].

\subsubsection{Moderating Variable}

The moderating variable in this study is industrial category. As mentioned above, industrial category can be further divided into two categories: the industrial products category and the consumer products category. The data were then collected from Datastream. The industrial category was thus measured by a dichotomous variable coded as one for the industrial products category and zero for the consumer products category.

\subsubsection{Control Variables}

This study referred to prior studies which chose to control for the effects of responsible innovation factors, such as firm size, firm age, R\&D intensity, degree of internationalization, and organizational slack resources. Firm size has commonly been found to have important effects on the degree of innovativeness [60] and is measured in terms of total assets and number of employees [61]. A principal component method was utilized to form a composite factor score as the surrogate for a firm's size respectively. Firm age is computed as the difference between observation year and a firm's inception year [62]. This paper also controlled for the R\&D intensity of the firms because of its effect on innovation performance. This concept was quantified using the ratio of R\&D expenses to sales. Following Onetti et al. [63], innovation and the degree of internationalization are deeply intertwined. In addition, the sample included multinational companies; this study therefore used the ratio of foreign sales divided to the total sales of the firm to control for the effect of internationalization. This study also controlled the effect of organizational slack resources. Two items were used to measure slack resources, namely, the ratio of equity to debt and the ratio of selling, general, and administrative expenses to net sales [64]. Then, this study used the principal component method to form a composite factor score as the surrogate for a firm's slack resources.

\section{Results}

Table 1 presents the means, standard deviations, and correlation coefficients. The moderate correlation between long-term orientation and organizational virtue orientation is interesting. This correlation is unexpected because the dimensions of organizational virtue orientation comprise 
integrity, empathy, warmth, courage, conscientiousness, and zeal [39], which are not conceptually related to a long-term orientation. This finding might encourage future examination of these two concepts. Nonetheless, to ease the concern of multicollinearity, the procedures suggested by Aiken and West [65] were followed to standardize the independent variables of the original terms and their interaction terms. No variance inflation factor (VIF) score exceeds 4.1, with a mean score of 1.6, which is well below the threshold of 10 that is typically considered to represent a potential for multicollinearity [66]. To ease concerns regarding the sample selection, the Kolmogorov-Smirnov (K-S) test was used to determine whether the sample, in terms of responsible innovation, fit a normal distribution. The result showed that the total sample in this study fit the assumption of normal distribution $(p>0.05)$.

Table 2 presents the results of the panel regression analysis. The significance of the Hausman test suggests that the fixed-effects model is a better model than the random-effects model $[58,67]$. This study used a panel linear regression of fixed-effects model design, in which the control variables are first entered as the baseline model and the independent variables and interaction terms are then alternately entered into the models to test the hypotheses. To test the direct effect of strategic orientations, the variables of long-term, profitability, and organizational virtue orientation were entered into Model 2. The results show that the long-term orientation is positively related to responsible innovation at the $\alpha=0.01$ level $(\beta=1.672, p<0.01)$. Profitability orientation is negatively related to responsible innovation at the $\alpha=0.01$ level $(\beta=-0.675, p<0.01)$, and organizational virtue orientation is positively related to responsible innovation at the $\alpha=0.01$ level $(\beta=0.224, p<0.01)$. Therefore, H1a, H1b, and H2 are supported.

Model 3-5 adds the moderating variable of stakeholder involvement. The results of Model 3 show that the regression coefficient for the interaction term between long-term orientation and responsible innovation was negatively significant $(\beta=-0.630, p<0.01)$. Model 4 shows that the coefficient of the interaction term between profitability orientation and responsible innovation was not significant $(\beta=0.039, p>0.10)$, whereas Model 5 shows the coefficient of the interaction term between organizational virtue orientation and responsible innovation was negatively significant $(\beta=-0.757$, $p<0.01$ ). Therefore, $\mathrm{H} 3 \mathrm{a}$ and $\mathrm{H} 4$ were supported, whereas $\mathrm{H} 3 \mathrm{~b}$ was not.

To further aid the understanding regarding the moderating effects, this study used the results from Model 3-5 to plot figures. Following Dawson and Richter [68] to plot the interaction effects, the binary variable should have possible values of 0 and 1 and should not be standardized. Other independent variables are both centered around zero and are scaled such that they have a standard deviation of 1 . As Figures 1 and 2 show, the positive relationship between long-term focus and responsible innovation is weakened in the industrial products category, compared with the consumer products category situation. Similarly, in the scenario of organizational virtue orientation, the positive relationship between long-term orientation and responsible innovation becomes negative in the industrial products category, and is much weaker than that in the consumer products category. This can be further evidence for the supported hypotheses.

As a robust test, this research additionally used the words proposed by March [69] to measure innovativeness to calculate responsible innovation in an alternative manner. March [69] has proposed two means of organization learning, which have been used as indicators of exploitative or exploratory innovation [55]. Whereas exploitative innovation includes exploit*, refine*, choice*, production*, efficien*, select*, implement*, and execut ${ }^{*}$, exploration innovation includes explor ${ }^{*}$, search ${ }^{*}$, variation*, risk*, experiment*, play*, flexib*, discover*, and innovat*. (The wildcard "** can represent any characters). This research separately used these two measures combined with CSR rankings to form the dependent variable-responsible innovation. All the models were run and found that the results are consistent with the findings above. 
Table 1. Means, standard deviation, and correlation coefficients.

\begin{tabular}{|c|c|c|c|c|c|c|c|c|c|c|c|}
\hline & Mean & S. D. & 1 & 2 & 3 & 4 & 5 & 6 & 7 & 8 & 9 \\
\hline 1. Responsible innovation & 0.222 & 0.924 & 1 & & & & & & & & \\
\hline 2. Long-term orientation & 0.548 & 0.229 & $0.378^{* * *}$ & 1 & & & & & & & \\
\hline 3. Profitability orientation & 1.078 & 0.407 & $-0.203^{* * *}$ & 0.080 & 1 & & & & & & \\
\hline 4. Organizational virtue orientation & 0.008 & 1.000 & $0.477^{* * *}$ & $0.516^{* * *}$ & $-0.165^{* * *}$ & 1 & & & & & \\
\hline 5. Industrial category & 0.384 & 0.487 & -0.100 * & $0.096^{*}$ & $-0.232^{* * *}$ & $-0.183^{* * *}$ & 1 & & & & \\
\hline 6. Firm size ${ }^{\text {a }}$ & 0.001 & 1.005 & -0.030 & 0.050 & -0.030 & -0.025 & 0.044 & 1 & & & \\
\hline 7. Firm age & 69.677 & 50.137 & -0.073 & -0.062 & $0.102 * *$ & -0.049 & $-0.103^{* *}$ & $0.246^{* * *}$ & 1 & & \\
\hline 8. $R \& D$ intensity & 1.413 & 3.624 & -0.030 & 0.024 & -0.083 & -0.006 & $0.278^{* * *}$ & $-0.103 * *$ & $-0.185^{* * *}$ & 1 & \\
\hline 9. Degree of internationalization & 31.753 & 31.492 & 0.027 & -0.057 & $-0.169 * * *$ & 0.014 & $0.195^{* * *}$ & $0.295^{* * *}$ & $0.333^{* * *}$ & $0.171^{* * *}$ & 1 \\
\hline 10. Organizational slack ${ }^{\mathrm{a}}$ & 0.000 & 1.000 & $0.166^{* * *}$ & 0.056 & 0.013 & $0.260^{* * *}$ & $-0.186^{* * *}$ & -0.054 & -0.011 & $0.104^{* *}$ & -0.070 \\
\hline
\end{tabular}

${ }^{*} p<0.1 ; * * p<0.05 ;{ }^{* * *} p<0.01 ; \mathrm{n}=87$, Observations = 372; a: A composite measure of firm size and organizational slack using the factor scores. 
Table 2. Results of panel regression analysis predicting responsible innovation.

\begin{tabular}{|c|c|c|c|c|c|c|}
\hline & Model 1 & Model 2 & Model 3 & Model 4 & Model 5 & Model 6 \\
\hline \multicolumn{7}{|l|}{ Control variables } \\
\hline \multirow{2}{*}{ Firm size } & 0.003 & -0.080 & -0.012 & -0.080 & -0.118 & -0.039 \\
\hline & $(0.187)$ & $(0.155)$ & $(0.146)$ & $(0.155)$ & $(0.149)$ & $(0.143)$ \\
\hline \multirow{2}{*}{ Firm age } & $-0.088^{* * *}$ & -0.019 & -0.019 & -0.019 & -0.015 & -0.015 \\
\hline & $(0.026)$ & $(0.023)$ & $(0.022)$ & $(0.023)$ & $(0.022)$ & $(0.021)$ \\
\hline \multirow{2}{*}{ R\&D intensity } & 0.015 & 0.052 & 0.028 & 0.052 & 0.061 & 0.034 \\
\hline & $(0.104)$ & $(0.085)$ & $(0.081)$ & $(0.086)$ & $(0.082)$ & $(0.079)$ \\
\hline Degree of & 0.000 & -0.001 & -0.001 & -0.001 & -0.000 & -0.001 \\
\hline internationalization & $(0.004)$ & $(0.003)$ & $(0.003)$ & $(0.003)$ & $(0.003)$ & $(0.003)$ \\
\hline \multirow{2}{*}{ Organizational slack } & $0.690^{* * *}$ & $0.253 * *$ & $0.197 * *$ & $0.250 * *$ & 0.183 * & 0.137 \\
\hline & $(0.111)$ & $(0.099)$ & $(0.093)$ & $(0.099)$ & $(0.096)$ & $(0.092)$ \\
\hline \multicolumn{7}{|l|}{ Predictor variables } \\
\hline Long-term orientation & & $\begin{array}{l}1.672 * * * \\
(0.273)\end{array}$ & $\begin{array}{l}2.944 * * * \\
(0.333)\end{array}$ & $\begin{array}{l}1.673^{* * *} \\
(0.274)\end{array}$ & $\begin{array}{c}1.585^{* * *} \\
(0.263)\end{array}$ & $\begin{array}{l}2.865^{* * *} \\
(0.348)\end{array}$ \\
\hline \multirow[t]{2}{*}{ Profitability orientation } & & $-0.675^{* * *}$ & $-0.710^{* * *}$ & $-0.712^{* * *}$ & $-0.632^{* * *}$ & $-0.900^{* * *}$ \\
\hline & & $(0.145)$ & $(0.137)$ & $(0.178)$ & $(0.140)$ & $(0.171)$ \\
\hline \multirow{2}{*}{$\begin{array}{l}\text { Organizational virtue } \\
\text { orientation }\end{array}$} & & $0.224^{* * *}$ & $0.103 *$ & $0.221^{* * *}$ & $0.308^{* * *}$ & $0.142 * *$ \\
\hline & & $(0.059)$ & $(0.059)$ & $(0.059)$ & $(0.059)$ & $(0.065)$ \\
\hline \multirow{2}{*}{ Industrial category } & & & -4.617 & -4.339 & -3.497 & -3.607 \\
\hline & & & (5.345) & $(5.687)$ & $(5.461)$ & $(5.220)$ \\
\hline \multicolumn{7}{|l|}{ Interaction term } \\
\hline \multirow{2}{*}{$\begin{array}{l}\text { Long-term orientation } \times \\
\text { Industrial category }\end{array}$} & & & $-0.630^{* * *}$ & & & $-0.618^{* * *}$ \\
\hline & & & $(0.105)$ & & & $(0.116)$ \\
\hline Profitability orientation $x$ & & & & 0.039 & & $0.232 * *$ \\
\hline Industrial category & & & & $(0.110)$ & & $(0.110)$ \\
\hline \multirow{2}{*}{$\begin{array}{l}\text { Organizational virtue } \\
\text { orientation } \times \text { Industrial } \\
\text { category }\end{array}$} & & & & & $-0.757 * * *$ & $-0.468^{* * *}$ \\
\hline & & & & & $(0.156)$ & $(0.159)$ \\
\hline F value & $12.720^{* * *}$ & $29.100^{* * *}$ & $33.170 * * *$ & $25.800 * * *$ & $30.570 * * *$ & $29.980 * * *$ \\
\hline $\mathrm{R}^{2}$ & 0.185 & 0.457 & 0.520 & 0.457 & 0.499 & 0.546 \\
\hline Hausman test & $56.100 * * *$ & $42.760^{* * *}$ & $42.020 * * *$ & $44.720^{* * *}$ & $25.020 * * *$ & $36.610 * * *$ \\
\hline
\end{tabular}

Notes: ${ }^{*} p<0.1 ;{ }^{* *} p<0.05 ;{ }^{* * *} p<0.01$ (two-tailed); $\mathrm{n}=87$, Observations $=372$; regression coefficients are non-standardized, and numbers in parentheses are standard errors.

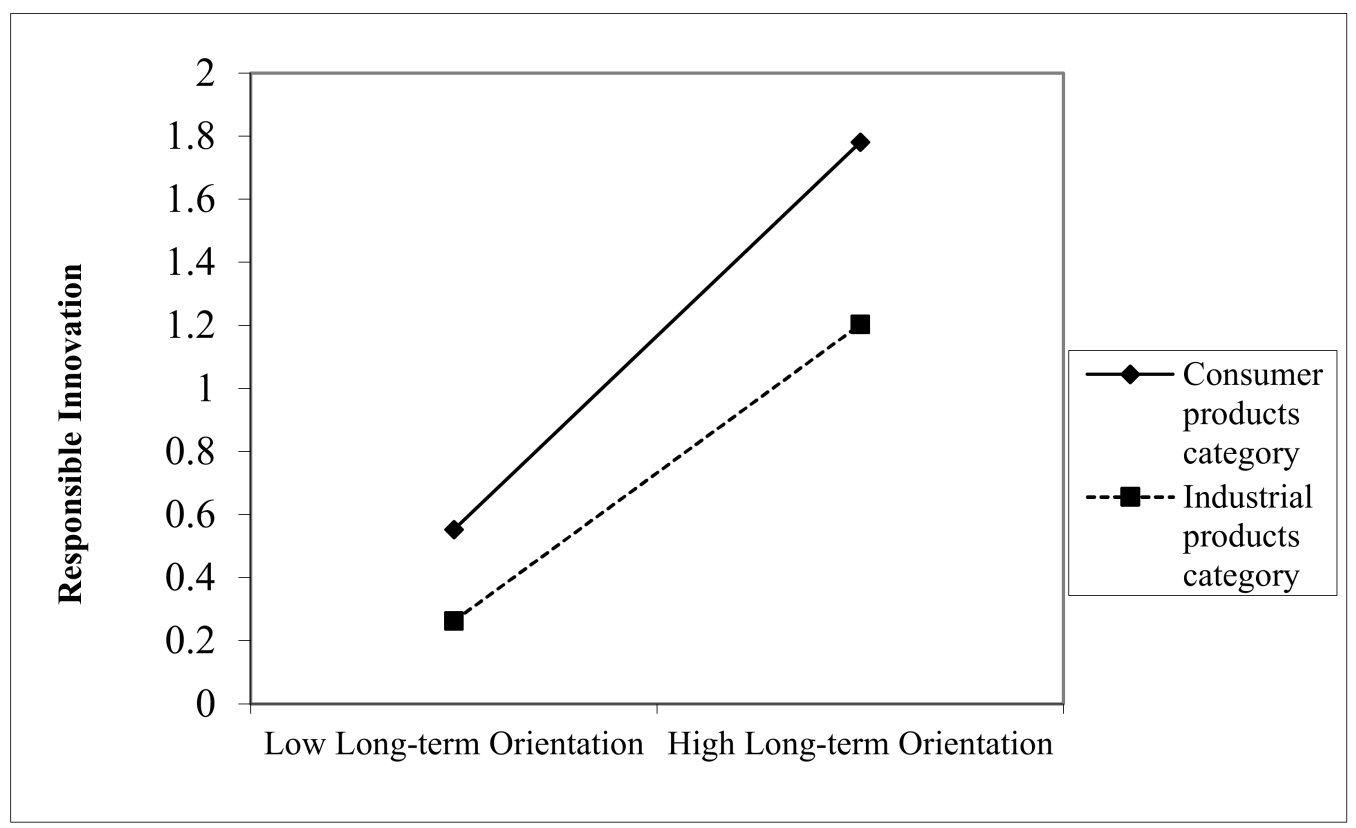

Figure 1. The interactive effect of long-term orientation and industrial category on responsible innovation. 


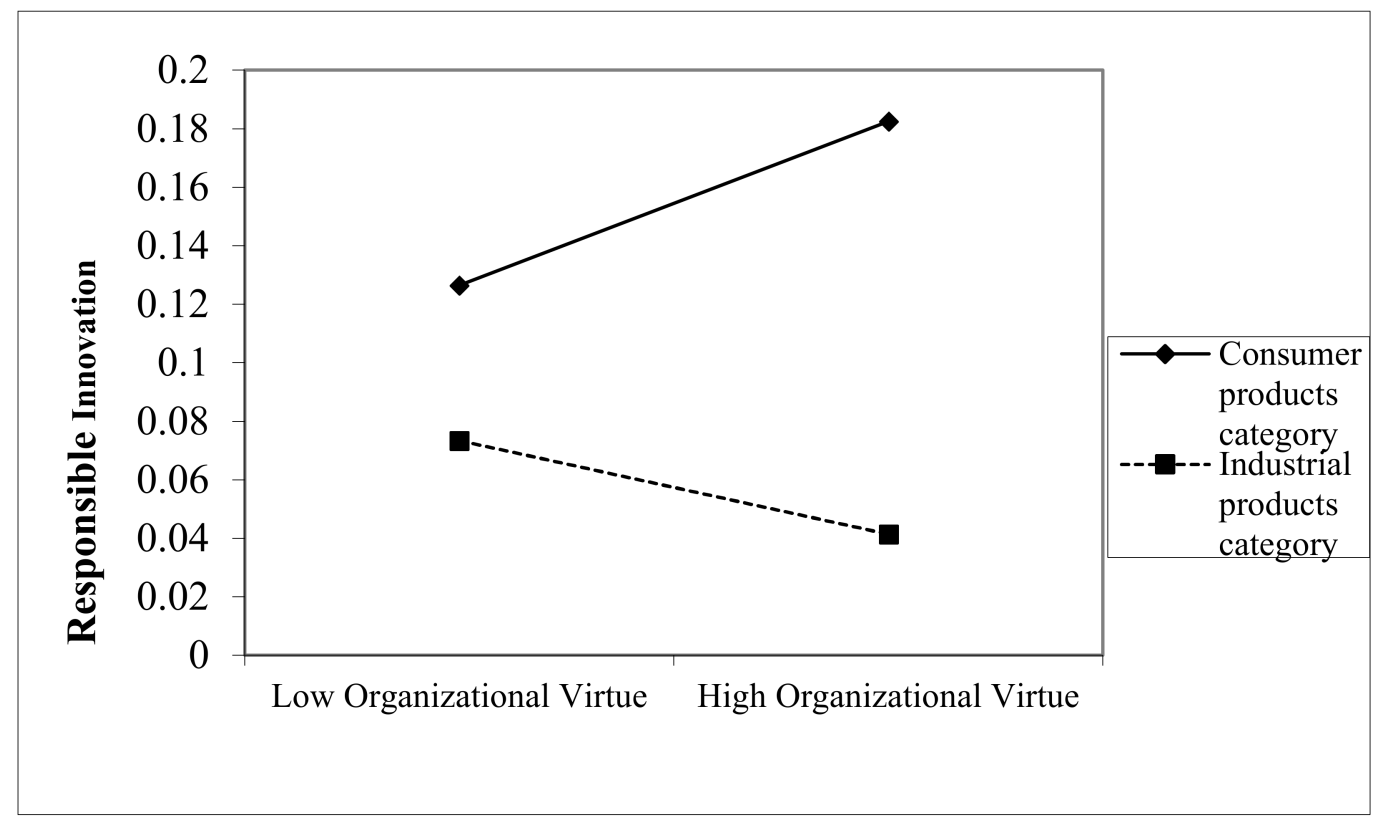

Figure 2. The interactive effect of organizational virtue orientation and industrial category on responsible innovation.

\section{Discussion}

This study was motivated by the increasing theoretical attention to responsible innovation and asks the question of what factors encourage firms to engage in responsible innovation and what moderating effect industrial category has in this process. Complementing existing studies using either conceptual research [3,18], in-depth interviews [8], or case studies $[4,19,20]$, this study provides empirical data to enrich the theoretical basis for responsible innovation. Because responsible innovation comes from the practical call to solve unwanted innovation consequences, the build-up of related theory can enrich the understanding and further pursuit of this idea. The result supports a framework that concurrently considers both internal organizational orientations and external industrial environment, which paves the way for further examination of responsible innovation.

Responsible innovation is regarded as a new norm to guide innovation activities to avoid the detrimental outcomes of innovation and improve conditions for people and the planet [7]. When more firms are willing to join in this request, the societal and economic environment of human society can be more sensible. It is this point where this research starts. This study therefore first proposed testing several hypotheses regarding motivations for engaging in responsible innovation that appear in the literature, namely, strategic and virtue orientations, and additionally examines whether this link differs in different industrial categories. The investigations produced interesting results.

To summarize, the results show that both internal and external factors affect the adoption of responsible innovation, yet different effects were found. Specifically, firms' organizational orientations play a key role in facilitating or hindering the level of their responsible innovation engagement. In terms of strategic orientations, the well-accepted categories of strategies-long-term and profitability orientations-were employed to test their effects on engagement in responsible innovation. The result shows that long-term orientation is positively associated with responsible innovation, whereas profitability orientation is negatively associated with responsible innovation. This result is consistent with the expectation that firms with a long-term orientation tend to treat the consequence of a firm using a longer time horizon and emphasize the effectiveness of the company's policies, which is consistent with the philosophy that responsible innovation adopts [34,35]. In contrast, firms using a profitability orientation tend to make decisions based on immediate returns or present issues [37]. However, most issues that responsible innovation aims to address are related to the future 
or something unexpected. A cautious or thorough scanning for every aspect of the decision is required, which makes anticipation, reflection, deliberation, and responsiveness [18] unfavorable.

Regarding the organizational virtue orientation, a positive association with responsible innovation was found. This result is also consistent with the proposed relationship. Organizational virtue orientation is a newly established concept using text analytics and applied most often in business research $[39,41,43]$. An organizational virtue orientation encourages firms to behave in an ethical manner. From the start of the discussion of responsible innovation, the core is about how human beings can avoid harm and/or do something good not only economically but also socially and environmentally. The positive relationship was expected.

The framework also investigated the different effects depending on industrial category. As predicted, firms in the industrial products category are required to address more powerful and organized stakeholders, such as suppliers or buyers [52]. This moderating effect can be seen in both the long-term orientation and organizational virtue orientation scenarios, such that the organizational orientations-responsible innovation link becomes weaker in the industrial products category. This result is understandable because, compared to the consumer products category, the industrial products category brings more powerful players with higher stakeholder involvement which results in more tensions and requests for firms to engage in responsible innovation [50]. When firms endeavor to move to adopt responsible innovation, the status the focal firm is occupying matters significantly. If a firm needs to collaborate with other companies, such as suppliers and manufacturers frequently, this might yield challenges because not all firms have the same pace or thoughts about adoption of responsible innovation. Even though a firm attempts to keep their long-term orientation or organizational virtue orientation to engage in responsible innovation, the structure of the industry or forces coming from partner firms may make this endeavor more difficult [70].

Beyond the expectation, however, this study does not find this effect emerges in the situation of profitability orientation-responsible innovation relationship. It is interesting that the result is homogeneous regardless of the industries of the focal firms. One possible explanation might be that the idea of "the social responsibility of business is to increase its profit" [38] is deeply rooted in the managers' mind in this type of firm. Firms with a profitability orientation tend not to engage in responsible innovation due to the costs and conflicts that it might incur; this philosophy is consistently well accepted regardless of the industry in which these firms reside.

\section{Conclusions}

With increasingly more debates about where technology advancement can lead the human society to, responsible innovation emerges as a possible solution to the dilemma of convenience and harm. In this paper, this research took the road paved by previous studies and calls to study the internal and external factors that might facilitate or dampen the adoption of responsible innovation. The empirical results provide meaningful implications for theory and practice.

Theoretically, previous studies have accumulated plenty of knowledge regarding responsible innovation. This stream of literature either provides a conceptual framework or in-depth studies to lay a sound foundation for further study regarding this topic. Specifically, some scholars have attempted to provide a conceptual framework such that academia can keep up with the pace of discussion $[3,18]$. Other studies have aimed at determining the process or what roles different participants might play using case analyses $[4,19,20]$. Building upon these studies, this research further enriches the understanding of the concept by proposing a framework and emphasizing its foundations or triggers using a large amount of empirical data. This research developed a measurement that combines CSR with innovation to represent responsible innovation. While the discussion of the definition is still ongoing, comprising these two elements is a possible and available means to study responsible innovation. This measurement and the theoretical framework can contribute to this field and open a new agenda for this line of research. 
The methodology applied in this paper is also novel in this field. Text analytics has been revived as a means to address the "big data" issue [71,72]. Using a robust procedure, this study used this technique that can help us understand what the companies say about themselves. This approach is different from ratings reviewed by experts and complements the previous methodology (e.g., [14,15]). This study specifically used this method to measure strategic orientations and organizational virtue orientation. Since orientation is an abstract concept, the utilization of text analysis can help us understand the mindset of the organization rather than just borrowing the measurement from the individual level, which has been criticized as being inapplicable [40]. The present study provides evidence from the company's annual reports, which are public and can be analyzed with flexibility. These public data can bring us more information than previously thought.

Practically, increasingly many investors are requesting that firms disclose their attitudes toward ESG ratings [17]. The methodology reported here can be a good starting point to signal whether and how well a focal firm is addressing this issue. Regarding firms, this study provides a starting point to consider when a firm prepares to engage in responsible innovation. That is, firms should review their own organizational orientations or culture to anticipate the challenges that they might encounter. Additionally, these firms also need to deliberate about which industrial environment they are residing in to prepare themselves to cross the hurdle. When they are in the industrial products category, the firm might need more time to persuade or communicate with stakeholders; in the consumer products category, the required effort might be lower.

Although these results are compelling, this study has several limitations that warrant additional research. First, text analytics was employed, which can potentially be used to analyze a large amount of data. Due to the termination of this evaluation by Fortune magazine, it was not possible to use further rankings according to the same standard. Future studies are encouraged to seek additional data to evaluate the hypotheses. Second, the vocabularies that this study used can be applied to additional firms. Scholars are also encouraged to apply the vocabularies to many firms to predict responsible innovation and then to follow up to examine how good the predictions are by studying a number of individual firms and scoring them. Third, caution should be applied when explaining results derived from text analytics; the processing of the text should follow a strict procedure to improve its validity. Fourth, the internal foundations discussed in this paper are strategic and virtue orientations; future studies can discuss other motivations, such as institutional pressures or competitive levels. Finally, this research did not find evidence for a moderating effect of industry category on the profitability orientation-responsible innovation link. Future studies might thus examine the different stakeholders involved in this process to determine whether their various goals and values conflict with each other in reducing this effect using other research designs.

Supplementary Materials: The following is available online at http:/ / www.mdpi.com/2071-1050/10/4/1033/s1, Table S1: Sample Companies in the Study; Table S2: An Archive procedure about how Fortune Magazine pick the Companies.

Acknowledgments: This work received research grants from the Ministry of Science and Technology in Taiwan; the grant number is MOST 103-2410-H-259-074-MY2.

Conflicts of Interest: The author declares no conflicts of interest.

\section{References}

1. Chesbrough, H. Open Innovation: The New Imperative for Creating and Profiting from Technology; Harvard Business School Press: Boston, MA, USA, 2003.

2. Drucker, P.F. Innovation and Entrepreneurship; Collins: New Yord, NY, USA, 1985.

3. Stilgoe, J.; Owen, R.; Macnaghten, P. Developing a framework for responsible innovation. Res. Policy 2013, 42, 1568-1580. [CrossRef]

4. Pandza, K.; Ellwood, P. Strategic and ethical foundations for responsible innovation. Res. Policy 2013, 42, 1112-1125. [CrossRef]

5. Jonas, H. The Imperative of Responsibility; University of Chicago Press: Chicago, IL, USA, 1984. 
6. Groves, C. Technological futures and non-reciprocal responsibility. Int. J. Humanit. 2006, 4, 57-61.

7. Von Schomberg, R. Towards Responsible Research and Innovationin the Information and Communication Technologies and Security Technologies Fields; European Commission: Brussels, Belgium, 2011.

8. Chatfield, K.; Iatridis, K.; Stahl, B.; Paspallis, N. Innovating Responsibly in ICT for Ageing: Drivers, Obstacles and Implementation. Sustainability 2017, 9, 971. [CrossRef]

9. Amos, J. French GM-fed Rat Study Triggers Furore. Available online: http://www.bbc.co.uk/news/scienceenvironment-19654825 (accessed on 28 March 2018).

10. Stahl, B.; Obach, M.; Yaghmaei, E.; Ikonen, V.; Chatfield, K.; Brem, A. The Responsible Research and Innovation (RRI) Maturity Model: Linking Theory and Practice. Sustainability 2017, 9, 1036. [CrossRef]

11. Auer, A.; Jarmai, K. Implementing Responsible Research and Innovation Practices in SMEs: Insights into Drivers and Barriers from the Austrian Medical Device Sector. Sustainability 2018, 10, 17. [CrossRef]

12. Blanco, B.; Guillamón-Saorín, E.; Guiral, A. Do non-socially responsible companies achieve legitimacy through socially responsible actions? The mediating effect of innovation. J. Bus. Ethics 2013, 117, 67-83. [CrossRef]

13. Schumpeter, J.A. The Theory of Economic Development; Harvard University Press: Cambridge, MA, USA, 1934.

14. Hull, C.E.; Rothenberg, S. Firm performance: The interactions of corporate social performance with innovation and industry differentiation. Strateg. Manag. J. 2008, 29, 781-789. [CrossRef]

15. McWilliams, A.; Siegel, D. Corporate social responsibility and financial performance: Correlation or misspecification? Strateg. Manag. J. 2000, 21, 603-609. [CrossRef]

16. Dreyer, M.; Chefneux, L.; Goldberg, A.; von Heimburg, J.; Patrignani, N.; Schofield, M.; Shilling, C. Responsible Innovation: A Complementary View from Industry with Proposals for Bridging Different Perspectives. Sustainability 2017, 9, 1719. [CrossRef]

17. Khalamayzer, A. The race to embrace ESG ratings. GreenBiz. 2017. Available online: https:/ /www.greenbiz. com/article/race-embrace-esg-ratings (accessed on 19 November 2017).

18. Owen, R.; Stilgoe, J.; Macnaghten, P.; Gorman, M.; Fisher, E.; Guston, D. A Framework for Responsible Innovation. In Responsible Innovation; John Wiley \& Sons, Ltd.: Hoboken, NJ, USA, 2013; pp. 27-50.

19. Bruijnis, M.R.N.; Blok, V.; Stassen, E.N.; Gremmen, H.G.J. Moral "lock-in" in responsible innovation: The ethical and social aspects of killing day-old chicks and its alternatives. J. Agric. Environ. Ethics 2015, 28, 939-960. [CrossRef]

20. Wodzisz, R. Case Study of R-1234yf Refrigerant: Implications for the Framework for Responsible Innovation. Sci. Eng. Ethics 2015, 21, 1413-1433. [CrossRef] [PubMed]

21. Vagnani, G. Exploration and long-run organizational performance: The moderating role of technological interdependence. J. Manag. 2015, 41, 1651-1676. [CrossRef]

22. Zavyalova, A.; Pfarrer, M.D.; Reger, R.K.; Shapiro, D.L. Managing the message: The effects of firm actions and industry spillovers on media coverage following wrongdoing. Acad. Manag. J. 2012, 55, 1079-1101. [CrossRef]

23. Shin, T.; You, J. Pay for Talk: How the Use of Shareholder-Value Language Affects CEO Compensation. J. Manag. Stud. 2017, 54, 88-117. [CrossRef]

24. Zachary, M.A.; McKenny, A.; Short, J.C.; Payne, G.T. Family business and market orientation: Construct validation and comparative analysis. Fam. Bus. Rev. 2011, 24, 233-251. [CrossRef]

25. Donaldson, T.; Dunfee, T.W. Toward a unified conception of business ethics: Integrative social contracts theory. Acad. Manag. Rev. 1994, 19, 252-284.

26. McKenny, A.F.; Short, J.C.; Payne, G.T. Using Computer-Aided Text Analysis to Elevate Constructs. Organ. Res. Methods 2013, 16, 152-184. [CrossRef]

27. Sykes, K.; Macnaghten, P. Responsible innovation-Opening up dialogue and debate. In Responsible Innovation; John Wiley \& Sons, Ltd.: Hoboken, NJ, USA, 2013; pp. 85-107.

28. Gatignon, H.; Jean-Marc, X. Strategic Orientation of the Firm and New Product Performance. J. Mark. Res. 1997, 34, 77-90. [CrossRef]

29. Mu, J.; Thomas, E.; Peng, G.; Di Benedetto, A. Strategic orientation and new product development performance: The role of networking capability and networking ability. Ind. Mark. Manag. 2017, 64, 187-201. [CrossRef]

30. Hsieh, C.; Nickerson, J.A.; Zenger, T.R. Opportunity discovery, problem solving and a theory of the entrepreneurial firm. J. Manag. Stud. 2007, 44, 1255-1277. [CrossRef] 
31. Barney, J. Firm Resources and Sustained Competitive Advantage. J. Manag. 1991, 17, 99-120. [CrossRef]

32. Venkatraman, N. Strategic Orientation of Business Enterprises: The Construct, Dimensionality, and Measurement. Manag. Sci. 1989, 35, 942-962. [CrossRef]

33. Lumpkin, G.T.; Brigham, K.H.; Moss, T.W. Long-term orientation: Implications for the entrepreneurial orientation and performance of family businesses. Entrep. Reg. Dev. 2010, 22, 241-264. [CrossRef]

34. Johnson, J.L.; Martin, K.D.; Saini, A. The role of a firm's strategic orientation dimensions in determining market orientation. Ind. Mark. Manag. 2012, 41, 715-724. [CrossRef]

35. Adam, B.; Groves, C. Futures Tended: Care and Future-Oriented Responsibility. Bull. Sci. Technol. Soc. 2011, 31, 17-27. [CrossRef]

36. Grinbaum, A.; Groves, C. What is "responsible" about responsible innovation? Understanding the ethical issues. In Responsible Innovation; John Wiley \& Sons, Ltd.: Hoboken, NJ, USA, 2013; pp. 119-142.

37. Brauer, M.F. The effects of short-term and long-term oriented managerial behavior on medium-term financial performance: Longitudinal evidence from Europe. J. Bus. Econ. Manag. 2013, 14, 386-402. [CrossRef]

38. Friedman, M. The social responsibility of business is to increase its profit. New York Times Magazine, 13 September 1970; 122-126.

39. Payne, G.T.; Brigham, K.H.; Broberg, J.C.; Moss, T.W.; Short, J.C. Organizational virtue orientation and family firms. Bus. Ethics Q. 2011, 21, 257-285. [CrossRef]

40. Chun, R. Ethical character and virtue of organizations: An empirical assessment and strategic implications. J. Bus. Ethics 2005, 57, 269-284. [CrossRef]

41. McLeod, M.S.; Moore, C.B.; Payne, G.T.; Sexton, J.C.; Evert, R.E. Organizational Virtue and Stakeholder Interdependence: An Empirical Examination of Financial Intermediaries and IPO Firms. J. Bus. Ethics 2016, 1-14. [CrossRef]

42. Cameron, K.S.; Bright, D.; Caza, A. Exploring the Relationships between Organizational Virtuousness and Performance. Am. Behav. Sci. 2004, 47, 766-790. [CrossRef]

43. Payne, G.T.; Moore, C.B.; Bell, R.G.; Zachary, M.A. Signaling Organizational Virtue: An Examination of Virtue Rhetoric, Country-Level Corruption, and Performance of Foreign IPOs from Emerging and Developed Economies. Strateg. Entrep. J. 2013, 7, 230-251. [CrossRef]

44. Eisenhardt, K.M.; Martin, J.A. Dynamic capabilities: What are they? Strateg. Manag. J. 2000, 21, $1105-1121$. [CrossRef]

45. Rivkin, J.W.; Siggelkow, N. Balancing Search and Stability: Interdependencies Among Elements of Organizational Design. Manag. Sci. 2003, 49, 290-311. [CrossRef]

46. Burns, T.; Stalker, G.M. The Management of Innovation; Tavistock: London, UK, 1961.

47. Eisenhardt, K.M. Making fast strategic decisions in high-velocity environments. Acad. Manag. J. 1989, 32, 543-576. [CrossRef]

48. Smith, K.G.; Smith, K.A.; Olian, J.D.; Sims, H.P.; O'Bannon, D.P.; Scully, J.A. Top management team demography and process: The role of social integration andcommunication. Adm. Sci. Q. 1994, 39, 412-438. [CrossRef]

49. Keegan, W.J.; Green, M.C. Global Marketing, 8th ed.; Pearson Education Limited: London, UK, 2016.

50. Frazier, G.L.; Rody, R.C. The Use of Influence Strategies in Interfirm Relationships in Industrial Product Channels. J. Mark. 1991, 55, 52-69. [CrossRef]

51. Lubberink, R.; Blok, V.; van Ophem, J.; Omta, O. Lessons for Responsible Innovation in the Business Context: A Systematic Literature Review of Responsible, Social and Sustainable Innovation Practices. Sustainability 2017, 9, 721. [CrossRef]

52. Chang, J. The effects of buyer-supplier's collaboration on knowledge and product innovation. Ind. Mark. Manag. 2017, 65, 129-143. [CrossRef]

53. Yakovleva, N.; Vazquez-Brust, D. Stakeholder Perspectives on CSR of Mining MNCs in Argentina. J. Bus. Ethics 2012, 106, 191-211. [CrossRef]

54. Voegtlin, C.; Scherer, A.G. Responsible Innovation and the Innovation of Responsibility: Governing Sustainable Development in a Globalized World. J. Bus. Ethics 2017, 143, 227-243. [CrossRef]

55. Kimbrough, S.; Chou, C.; Chen, Y.-T.; Lin, H. On developing indicators with text analytics: Exploring concept vectors applied to English and Chinese texts. Inf. Syst. E-Bus. Manag. 2014, 12, 385-415. [CrossRef]

56. OECD-EUROSTAT. Proposed Guidelines for Collecting and Interpreting Technological Innovation Data; OECD: Paris, France, 1997. 
57. He, Z.L.; Wong, P.K. Exploration vs. Exploitation: An Empirical Test of the Ambidexterity Hypothesis. Organ. Sci. 2004, 15, 481-494. [CrossRef]

58. Hausman, J.A. Specification tests in econometrics. Econometrica 1978, 46, 1251-1271. [CrossRef]

59. Short, J.C.; Broberg, J.C.; Cogliser, C.C.; Brigham, K.C. Construct validation using computer-aided text analysis (CATA): An illustration using entrepreneurial orientation. Organ. Res. Methods 2010, 13, 320-347. [CrossRef]

60. McGrath, R.G. Exploratory learning, innovative capacity, and managerial oversight. Acad. Manag. J. 2001, 44, 118-131. [CrossRef]

61. Haveman, H. Between a Rock and a Hard Place: Organizational Change and Performance Under Conditions of Fundamental Environmental Transformation. Adm. Sci. Q. 1992, 37, 48-75. [CrossRef]

62. Pérez-Luño, A.; Medina, C.C.; Lavado, A.C.; Cuevas, G. How social capital and knowledge affect innovation. J. Bus. Res. 2011, 64, 1369-1376. [CrossRef]

63. Onetti, A.; Zucchella, A.; Jones, M.V.; McDougall-Covin, P.P. Internationalization, innovation and entrepreneurship: Business models for new technology-based firms. J. Manag. Gov. 2012, 16, 337-368. [CrossRef]

64. Bromiley, P. Testing a Causal Model of Corporate Risk Taking and Performance. Acad. Manag. J. 1991, 34, 37-59. [CrossRef]

65. Aiken, L.S.; West, S.G. Multiple Regression: Testing and Interpreting Interactions; SAGE: Newbury Park, CA, USA, 1991.

66. Stevens, J.P. Applied Multivariate Statistics for the Social Science; Lawrence Erlbaum Associates: Mahwah, NJ, USA, 2002.

67. Breusch, T.S.; Pagan, A.R. The Lagrange multiplier test and its applications to model specification in econometrics. Rev. Econ. Stud. 1980, 47, 239-253. [CrossRef]

68. Dawson, J.F.; Richter, A.W. Probing three-way interactions in moderated multiple regression: Development and application of a slope difference test. J. Appl. Psychol. 2006, 91, 917-926. [CrossRef] [PubMed]

69. March, J.G. Exploration and exploitation in organizational learning. Organ. Sci. 1991, 2, 71-87. [CrossRef]

70. Bao, Y.; Li, Y.; Pang, C.; Bao, Y.; Yi, X. Do resource differences between manufacturers and suppliers help or hinder product innovation of manufacturers? The moderating role of trust and contracts. Ind. Mark. Manag. 2017, 64, 79-90. [CrossRef]

71. Chen, H.; Chiang, R.H.L.; Storey, V.C. Business intelligence and analytics: From big data to big impact. MIS Q. 2012, 36, 1165-1188.

72. Markham, S.K.; Kowolenko, M.; Michaelis, T.L. Unstructured text analytics to support new product development decisions. Res. Technol. Manag. 2015, 58, 30-38. 